\title{
Room 40 and German intrigues in Morocco: re-assessing the operational impact of diplomatic cryptanalysis during World War I
}

\author{
Harry Richards \\ University of Portsmouth
}

\begin{abstract}
During World War I, Germany sought to provoke numerous insurrections throughout the British and French Empires. Examining the influence of signals intelligence within one of these colonial settings provides an opportunity to measure the operational importance of wartime cryptanalysis. Through a careful analysis of the original intercepts, this article reconstructs the responses of Room 40, the Admiralty's cryptology department, to Germany's Moroccan intrigues and highlights the development of intelligence practices. It argues that strategies to deploy diplomatic intelligence emerged gradually, but that Germany's enduring support for Moroccan dissidents suggests diplomatic cryptanalysis only secured modest results within an operational context.
\end{abstract}

In the autumn of 1915, the Director of Naval Intelligence, Captain (later Admiral Sir) William Reginald Hall, commissioned George Young to lead a political section within Room 40 that was designed to break Germany's diplomatic codes. Despite Room 40's early progress against Germany's naval communications, their diplomatic codes were unsystematic, which made them far more difficult to penetrate since the numerical order of the figure group was entirely unrelated to the alphabetical order of the vocabulary. The political branch secured some minor success against Germany's Foreign Office codes in the winter of 1915, but with the advent of machinery in May 1916 that could solve one hundred groups a 
day, Room 40's diplomatic cryptanalysis became fully operational. Referred to as 'hat codes' they revealed Germany's most sensitive information, including a series of efforts intended to provoke an insurrection in Morocco. ${ }^{1}$

Though Britain's awareness of Germany's covert intrigues in Morocco was first revealed in the early 1920 s by the former head of Room 40, Sir Alfred Ewing, many historical accounts ignore this fact completely. ${ }^{2}$ Where it has been alluded to, the influence of British intelligence has only received superficial consideration. ${ }^{3}$ Admiral Sir William James, for instance, merely found that Room 40 was able to 'to follow closely on the tracks of the numerous German agents whose object it was to ... stir up revolution in India, Persia, Afghanistan, and Morocco'. ${ }^{4}$ Paul Gannon also acknowledged the naval cryptographer's awareness of Germany's Moroccan intrigues, but he refrained from offering any analysis. Instead, it was claimed that 'measuring the effectiveness of intelligence is extremely hard. Whether things would have turned out any differently in the political sphere without Room 40's access to these detailed intercepts is uncertain' ${ }^{5}$ Although James Wyllie and Michael McKinley briefly referenced A.E.W. Mason's cloak and dagger activities in Morocco, they depended almost entirely on his fictional repertoire as evidence for such exploits. 6 This level of scrutiny reflects the wider tradition of 'factional disclosure' within British.

In a secret Admiralty memorandum Young wrote that the reading of diplomatic correspondence 'made it possible to defeat German intrigues in Spain, Portugal, Ireland, and Morocco, including a series of risings in the latter country'. 8 But owing to a scarcity of source material, however, even by normal intelligence history standards, ascertaining Room 40's influence in this matter raises a number of issues. Without previous examinations of the French and German archival 
record, a single British perspective cannot fully appreciate the extent of Allied intelligence collaboration, nor can it analyse Room 40's intelligence product against confirmed German operations. Owing to a dearth of surviving intelligence assessments and reports, this article correlates information revealed by Room 40's original interceptions with circumstantial evidence in the press and the British Foreign Office in order to reconstruct events that transpired in Morocco and assess Young's claim. Using inferences gleaned from the intelligence product not only provides an insight into a hitherto neglected facet of Germany's clandestine operations, it also provides some important observations into Room 40 and its leader outside of the over studied and sensationalised episodes within the conventional Room 40 narrative. ${ }^{9}$

Though recent additions to the historiography of British World War I (WWI) signals intelligence have contested Room 40's strategic success, this paper considers the applicability of these revisions to an operational perspective. 10 Consequently, it highlights the developments in Room 40's understanding of diplomatic cryptanalysis by illustrating their increasing proficiency at deploying signals intelligence. Whereas previous studies have demonstrated the lack of intelligence distribution, this article also tentatively draws attention to the continued incoordination of British and Allied signals intelligence and Hall's reluctance for direct intervention, that both arose from an initial averseness to disseminate the intelligence product. ${ }^{11}$ Although these problems were gradually resolved during the conflict, they were to continually hinder the operational impact of Room 40's diplomatic cryptanalysis throughout the conflict. Germany's unrelenting support for Moroccan insurgents was therefore able to generate significant difficulties that continued to frustrate French colonial ambitions beyond 1918 . 


\section{Origin of German interest}

In response to Germany's growing claims to imperial expansion, Britain and France signed the Entente Cordiale in 1904, in the hope of concluding a generation of colonial disputes. While France finally endorsed Britain's authority in Egypt, Britain sanctioned France's claim to Morocco. ${ }^{12}$ The Moroccan Parliament, however, soon protested against increased colonial expansion and condemned the presence of all European advisors. ${ }^{13}$ With the assurance of German abetment, Sultan Abd al-Aziz called for an international conference at Algeciras. ${ }^{14}$ Germany hoped to capitalise on this opportunity, but it proved to be a disaster for their diplomatic credibility. Owing to Germany's failure to generate opposition, the legitimacy of French and Spanish influence in Morocco was fully endorsed by the international community. ${ }^{15}$ Following the Agadir Crisis, the Treaty of Fez was signed in 1912, which formally established European authority in Morocco. The area surrounding Tangier became an international zone with the remainder divided into two protectorates. Spain controlled the northern and France the southern zone. Notwithstanding the intensifying European influence, the Sultan was to remain in possession of the symbols of power, if not its substance, and thus in theory, Morocco was to remain a sovereign state.

Immediately following the outbreak of the WWI, the French interned numerous German citizens but efforts to curtail Germany's transgressions were frustrated by the colonial context. Although the Sultan was technically at war with Germany the country was administered by two individual governments. As a neutral power, the Spanish were not required to expel German citizens, which theoretically allowed

enemy agents to lead incursions into French Morocco from northern territories. 16 Consequently, Arthur Zimmermann, the German Secretary of State for Foreign Affairs, instructed the Madrid embassy to attach great importance to their 
Moroccan endeavours in the belief that an insurrection in Morocco would encourage revolution throughout North Africa. ${ }^{17}$ A rebellion would also serve German strategy for practical reasons. Germany purportedly valued Moroccan agricultural exports at 20 million francs in 1914, which they estimated would double each year thereafter and provide a significant relief to France's food deficit. ${ }^{18}$ Civil unrest also compelled France to increase their military presence in Morocco from 50,000 to 90,000 men, soldiers that would otherwise have been able to fight in France. ${ }^{19}$

Germany soon established a network of agents at Larache and Melilla in the Spanish zone to conduct their intrigues, but a prominent Moroccan collaborator was required for a successful insurrection. 20 Cultivating relations with factional leaders would also assist the incorporation of Morocco into Germany's projected empire, but the potential for a general uprising was continually setback by the difficulties associated with finding such a person. Their initial choice was the former Sultan Adb al-Aziz but tentative negotiations broke down shortly after the outbreak of war and German efforts turned to his elder brother, Muley Hafid. Hafid had originally come to power in 1908 as a champion of Moroccan resistance, which he remained committed to following his forced abdication in 1912. Hafid was also known to be strongly pro-German, which ensured he attracted substantial German interest. 21

As a neutral country, Spain was often the centre of espionage for both the Entente and Central Powers. So long as it remained directly removed from the attention of the Spanish public, however, Germany was permitted to undertake subversive activities against their enemies. 22 Under the instructions of the Ambassador and the military attaché, Prince Max von Ratibor and Major Albert 
Kalle, the German embassy in Madrid was responsible for covert action in Morocco. The wireless link between Berlin and Madrid, therefore, provided an invaluable source of intelligence that revealed highly confidential correspondence. The Naval Intelligence Division (NID) also assembled its largest network of agents under Colonel Charles Thoroton at Gibraltar. Thoroton enjoyed a close relationship with Hubert Lyautey, the French Resident-General, who allegedly considered British intelligence vital to Moroccan security. 23 The Sultan even honoured Thoroton in 1915 with the Order Ouissam Alaouite Chérifien, for undisclosed services to Morocco. 24 The primary role of British naval intelligence at Gibraltar, however, was to collect intelligence on U-boat operations and it is unclear how active they were against intrigues in Morocco. 25 Nevertheless, by June 1916 the wireless link had betrayed German relations with four prominent Moroccan rebels.

\section{Early inertia: Muley Hafid}

Germany's initial efforts in the region concentrated on returning Muley Hafid to the Moroccan throne. Hafid had already been proclaimed Sultan in 1908 during a time of deep civil disorder and increasing European encroachment. Although he had viciously opposed his predecessor, Adb al-Aziz, for consenting to European intervention, the prolonged revolt that plagued Hafid's reign eventually forced him to succumb to European pressure and accept the protectorate system. 26 Eventually, though, he refused to assist the French and began conspiring with dissident tribes committed to a jihad against the colonial authorities. 27 Within three months of his arrival, therefore, Lyautey removed Hafid in favour of his more compliant brother, Yusef ben Hassan. 28

By 1914, Hafid had been exiled to Spain and began openly declaring his 
allegiance to Germany. The British representatives there noted how Hafid had come under the influence of the German Consul at Barcelona and suggested that Germany intended to employ him in Morocco. At this time Room 40 had made little progress with diplomatic intercepts, and thus the primary source of information remained British representatives reporting on Hafid's indiscreet interviews with the Spanish press. ${ }^{29}$ Hafid proclaimed that he would once again occupy the Moroccan throne under the auspices of the Germans, who he believed would shortly overcome the French and declare Moroccan independence. 30 The advent of signals intelligence in this matter, however, did little to curtail Germany's relations with Hafid and suggests that Room 40's success within the field of diplomatic cryptanalysis was relatively slow to materialise.

In August 1915, Hall supplied the Foreign Office with a memorandum received from a French Naval Attaché apparently confirming Hafid's intention to initiate an insurgency in Morocco under the banner of holy war. While French naval intelligence had already contacted the British Foreign Office to discuss the matter, it nonetheless illustrates the importance of additional sources of intelligence and highlight's Hall's willingness to distribute this type of product. ${ }^{31}$ Despite Room 40's remarkably quick progress with German naval signals, during the opening twenty months of war diplomatic intelligence largely relied on unchanged methods of collection. This alone proved insufficient to restrict German operations, but as this episode suggests, the advent of signals intelligence did little to impede subsequent relations with Hafid. Thus, notwithstanding Room 40's willingness to deploy intelligence gathered on Germany's naval signals as early as 1914, and despite their growing capability at diplomatic cryptanalysis, they proved far less willing to distribute this type of product. 
By 1916, however, Germany had failed to use Hafid in any of their designs. This unintentionally gave Room 40 the advantage. The establishment of the Political Branch had significantly increased Room 40's ability to read Germany's diplomatic correspondence and transmissions betraying their relations with Hafid were first intercepted in March 1916. ${ }^{32}$ By this time Hafid had been complaining to the press about the suspicion surrounding him, which made the British Foreign Office doubt the credibility of reports alleging his relationship with Germany. ${ }^{33}$ Room 40, however, soon intercepted a message revealing German preparations to transport him to Morocco. This revealed that Hafid was a German agent and disclosed operational details that were unavailable through traditional sources. The embarkation was to take place at a sufficient distance from both the French coast and Gibraltar to preclude any chance of surprise intervention, while disembarkation was arranged near Melilla. 34 The importance of secrecy evident within their correspondence demonstrated the significance of Room 40's achievement. They could now be confident in their ability to intercept the most confidential German correspondence and monitor their conspiracies.

Less than a fortnight later the Spanish Prime Minister, Conde de Romanones, gave assurances that all the vigilance necessary was being applied to prevent Hafid from returning to Morocco. It seems clear, however, that this was not a result of Room 40's intelligence. On 28 April, a Foreign Office representative questioned whether Hafid should be considered an enemy, as there had been no evidence besides the French Naval Attaché's memorandum that he was a German agent. 35 The same argument was repeated again in May. 36 It therefore seems likely that Room 40 never divulged their intelligence confirming Hafid's allegiance. But this was to be of minor significance. On 15 June, Zimmermann informed the embassy that Hafid was no longer to be employed in this manner and plans to 
send him to Morocco were to be abandoned. 37 The exact reason why German plans were frustrated at the last moment remains unclear. Given the evidence to the contrary, though, it is unlikely that it resulted from Room 40's interference. Within the intercepted correspondence, for instance, Germany had questioned Hafid's intentions from the beginning, and later suspected that their plans had been betrayed by one of his Turkish associates. 38 Moreover, it also shows that they had begun considering numerous insurrectionary actions owing to a perceived lack of unity within Morocco. ${ }^{39}$ Given the apparent change in German strategy, the lingering doubts as to Hafid's intentions, and his ostensible disregard for security, there is little wonder why Germany abandoned their plans.

During the preliminary stages of German intrigues involving Muley Hafid, Room 40's inability to collect signals intelligence demonstrates the reliance upon traditional intelligence sources during the early stages of the war. Despite the collection of signals intelligence from late 1915, its impact was far from immediate. Instead of providing evidence that could support allegations made in the press, Hall's reluctance to distribute intelligence allowed suspicions to remain unconfirmed, which prevented an effective diplomatic response to Germany's interference in the region. 40

\section{Indirect intervention: El Hiba}

As one of the most powerful leaders of armed resistance, German ambitions soon turned to the pretender to the Moroccan Sultanate, Ahmed al-Hiba, most commonly known as El Hiba. 41 This afforded Room 40 a far greater opportunity to gather intelligence. During Germany's initial intrigues with Hafid, Room 40 had made little progress with diplomatic messages, as the shortage of staff meant that they were forced to focus on naval signals. ${ }^{42}$ Following their expansion and 
the establishment of the political branch they were far better equipped to deal with diplomatic correspondence. Despite the prospect of defeating German intrigues in Morocco, and Hall's apparent aptitude for successfully wielding intelligence, the evidence suggests that Room 40's cryptology was operationally insignificant. While Daniel Larsen has argued that Hall deliberately withheld intelligence to use as a political weapon in order to attack government positions or policies that he was personally opposed to, this episode further demonstrates his tendency to withhold intelligence. Since this information was of little political value to Hall, it reflects his inherent apprehensions about security that were to equally hinder success. 43 Having witnessed his father, Ma al-'Aynayn, lead the armed resistance during the first decade of the twentieth century, Hiba proclaimed himself Amir al-Mujahidin in 1912, and as the leader of all those fighting the holy war he vowed to expel the French from Morocco. With a force of 5000 men, he captured Marrakech with ease and quickly represented the greatest threat to French security. Room 40 first uncovered Germany's apparent plans to employ Hiba in December 1915 when intercepts revealed that agents in Mellila and Larache had established relations with him and other dissident rebels. 44 Further intercepts received in August suggested that Hiba was prepared to assist Germany in order to obtain complete authority and remove French colonial rule. 45 Agents responsible for conducting the operation were swiftly smuggled into the Sous and began work at Ifni to manage the affair. 46 In order to ensure a successful rebellion, the German General Staff had reportedly allocated two million marks to finance Hiba's undertaking. 47 Given the expense, this was a considerable operation and marked a significant opportunity for Room 40 to frustrate German objectives in the region.

Support for Hiba was inevitably hampered by the geopolitical situation since 
all German, Austrian and Turkish nationals had been banished from the French zone. Providing logistical support to Hiba who resided in a remote southern area of French Morocco would thus require successful covert action. Owing to the importance attached to the operation, German strategists began devising a method to provide the appropriate resources. By October, Zimmermann had evidently recognised the difficulty of supplying arms and sent instructions to the military attaché to obtain them independently, which Room 40 intercepted. 48 Even if the acquisition of arms proved successful, however, the problem of smuggling them into Morocco undetected remained an arduous task. In December 1915, despite the considerable difficulties in both its arrangement and execution, they began discussing the possibility of transporting war materials to Morocco using submarines. 49

In June 1916, Room 40 intercepted confirmation that German plans to covertly smuggle war materials to El Hiba were to proceed. Zimmermann informed Kalle that 'a line of communication for arms, money and persons will be arranged for the beginning of October by submarine to a port in Sus[sic] territory'.50 On 22 August, Room 40 obtained a more comprehensive account of the operation. The submarine's cargo was to include four German and Turkish agents, several machine guns, rifles, munitions, French military uniforms, substantial funds, and even 'flying machines'. Effective prevention, however, required the exact location and expected date of disembarkation. In August, the Madrid Embassy was informed that the location of disembarkation had been set as Wadi Arksis, Draa, or Wadi Assaka, of which the former was most likely. Hiba was also instructed to position lookout parties on the Moroccan coast in November. 51 On 4 September, Room 40 received confirmation that Wadi Arksis was to be the landing place. 52 Hiba approved the location of Wadi Arksis and by 7 October 
preparations for the submarine's arrival were complete. 53 On 27 October, Room 40 received reports that a submarine carrying four machine guns, one 7.9-inch gun, 1000 rifles, ammunition, and 50,000 francs had left Germany on 20 October for either Wadi Assaka or Draa on the French coast of Morocco. 54 Even with the last minute change in destination, the intelligence that Room 40 had collected afforded NID an incredible opportunity to prevent operational support for Moroccan insurgents from materialising.

Despite the opportunity signals intelligence had provided, Hall seemingly decided against direct intervention and instead preferred to inform the French of the submarine. How far he revealed the full extent of Room 40's intelligence is uncertain, but the arrival and disembarkation of the submarine suggests that the French either did not possess adequate intelligence or that they lacked the motivation to prevent its arrival. Of the two, the latter seems least likely. The notable French naval presence in the region indicates that they had been made aware of illicit activities there, but their failure to impede the operation suggests that they were perhaps ignorant of specific details. 55 Angry at the French failure to prevent the submarine's disembarkation, Admiral Oliver, the Director of Naval Operations, exclaimed; 'we warned the French of this possibility about six or eight weeks ago'. 56 The fact that NID warned them of a 'possibility' and not a confirmed operation implies that the full extent of their intelligence was not divulged. Crucially, however, if NID only warned the French 'six or eight weeks ago' they would have been unaware of the last minute change of destination, which was only received by Room 40 three weeks before its arrival. This piece of information was essential to the operation's success and the failure to divulge it demonstrates that inter-allied intelligence collaboration remained in its infancy. 
Nevertheless, aside from the operational failures, the intelligence gathered by Room 40 was to have an enduring impact on German intrigues involving Hiba. In January 1917, Hiba defeated Haida ou Mouiz, the chief supporter of the French in the Sous. This decisive victory added fresh impetus to the German campaign. Haida's death ensured Hiba's influence increased exponentially, and the threat of a full-armed resistance against the French became a real possibility. Accordingly, the Madrid embassy urgently sought to take full advantage and instructed Berlin to rapidly supply the necessary resources. 57 Upon realising that the French had been made aware of their previous attempt, the prospect of sending further supplies in a submarine was considered unfeasible, at least for the near future. 58 But by failing to prevent Germany's initial support, Hiba's unrelenting resistance continued until 1919, after the armistice precluded any further German involvement and when France was once again fully able to enforce its occupation.

While Peter Freeman has illustrated the lack of collaboration between Room 40 and MI1(b), the War Office's cryptology department, until the autumn of 1916, the involvement of French Intelligence in this matter suggests that British signals intelligence had equally begun to value the importance of inter-allied intelligence co-operation during this period. 59 The lack of complete disclosure, however, indicates that they continued to prioritise security over distribution and operational success, and that Hall had not yet determined an effective strategy for disseminating diplomatic intelligence. Although he may have lacked the confidence to wield signals intelligence independently and effectively in 1916, by 1917 Hall received reports of another German plot intending to smuggle precious wolfram ore on the Erri Berro; this time he would be ready to ensure that they did not succeed. 60 


\section{Direct action: Abdel Malek and Raisuli}

Following the difficulties of operating in French Morocco, Germany soon turned to dissidents within the Spanish zone. The first to accept German support was Abdul Malek. Malek was the grandson of Abdel Kader who had gained fame for his campaign of resistance in Algeria. 61 He had himself fought in the resistance against Adb al-Aziz in 1902, but deserted after certain defeat became unavoidable. Malek subsequently received a commission under Aziz and was appointed chief of police at Tangier by Muley Hafid, but soon began pursuing complete sovereignty over Morocco instead. 62 The second prominent rebel to align with Germany was Mawlay Ahmad al-Raysuni, commonly referred to as Raisuli. Descended from Mulai Idris, the founder of the Islamic Empire in Morocco, Raisuli abandoned his aristocratic lifestyle for a more adventurous and lucrative profession as a cattle thief. 63 Robbery soon escalated into more sinister crimes but following the abduction of an American businessman, the United States forced the Moroccan authorities to comply with Raisuli's demands and he was made governor of Tangier. Nonetheless, his extreme violence and tyranny quickly prompted a European intervention that removed him from power and led to his championing of Moroccan resistance. 64

Since German operations once again violated Spanish neutrality, Room 40's intelligence could potentially generate political difficulties for Germany and upset their Moroccan insurgencies. Although the Spanish had been made aware of suspicious German activities, convincing rebellious tribes to attack the French had occasioned a period of relative peace in their Protectorate. 65 The disunity within the Spanish military and a widespread aversion to any form of colonial counter-insurgency made a Spanish intervention practically impossible. 66 
Nevertheless, their increasingly weakened position in Morocco was cultivating fervent dissident activity, which the British assessed to be responsible for a growing popular hostility over the mismanagement of the conflict. 67 Thus, although the strict neutrality of the Spanish Government would most likely make an official protest redundant, inciting a popular condemnation of Germany's continued support for Moroccan dissidents could have proven productive. ${ }^{68}$ While there is a history of intelligence services employing the press to manipulate public opinion through leaking intelligence, Hall has been particularly identified as an early proponent of this tradition. ${ }^{69}$ Employing patriotic journalists to impede German support for Malek and Raisuli, therefore, reflects Hall's pioneering work in what was to become an important channel for future intelligence practice.

In June 1916, Raisuli accepted German support and demanded 1 million pesetas to finance his endeavour. Germany seemingly obliged and initially sent 300,000 with the remainder to follow the commencement of hostilities. 70 By March 1917, however, Raisuli had still not agreed to initiate action against the French. Despite proclaiming himself 'Sultan of the jihad', he insisted that he was unable to mount an offensive without first receiving additional arms and munitions, as well as the full subsidy promised to him. ${ }^{71}$ Raisuli gave assurances that upon receipt of such support he would instigate a movement against the French but by this point Germany distrusted his reassurances. ${ }^{72}$ They were prudent to doubt his credibility. According to numerous native reports, Raisuli often preached jihad but was unlikely to sever relations with Spain since they essentially financed him, guaranteed him unrestricted authority, and proposed to appoint him Grand Vizier. ${ }^{73}$ Since his deliberations with the Spanish continued, the German authorities decided to delay the subsidy intended for him. ${ }^{74}$ Fearing 
that his bluff had been called, Raisuli desperately sought German assistance, assuring them that his preparations were complete, and declared that he was ready and willing to commence hostilities against the French. 75

Whereas Raisuli never emphatically declared his intentions, Malek was firmly committed to insurrectionary action against the French. Malek's forces were well trained and led by German officers, mostly deserters from the French Foreign Legion. 76 By the beginning of March 1917, he had defeated the French during several engagements and began attracting substantial support from several rebellious tribes. 77 Following his victories and the arrival of fresh insurgents, further operations were constrained by a severe lack of ammunition. Since Spain had recently expelled the German consul at Tetouan for intriguing with Malek, Germany postponed the payment of one million pesetas for the purchase of munitions. 78 Less than two weeks later, though, Berlin instructed Kalle to send Malek the full subsidy; their reckless disregard towards Spanish relations possibly prompted by the United States' declaration of war four days earlier. 79

Hugh Cleland Hoy, Hall's former private secretary, intimated that Room 40 achieved some minor operational success against Abdel Malek during 1917. Decoded messages supposedly revealed Germany's plans to dispatch another Uboat to Morocco, this time to a site near Larache, in order to resupply Malek's insurgency. Hoy claimed that these interceptions were handed to the French Naval Attaché, who promptly transmitted the information to the naval authorities in Paris. The submarine arrived on schedule and was destroyed along with its prized cargo. Aside from the undoubted success that this operation represented, Malek had already received sufficient support that ensured his campaign continued and Germany was still capable and willing to provide further 
assistance. 80 Consequently, it was only through exploiting the issues of Spanish neutrality that German intrigues could be more permanently terminated.

In April 1918, a press campaign in The Times unleashed a scathing attack on German intrigues in Morocco, which was arguably facilitated by leaked intelligence. In comparison, three articles published in December 1915 reported German intrigues in Morocco, but they were hardly a feat of investigative journalism. With no mention of specific plots or Moroccan agents, they merely gave a vague account of Germany's perceived intentions in Morocco. 81 Between December 1915 and April 1918, four further articles presumed the existence of German subversions in Morocco, while three others reported German propaganda in the region. Yet between 2 April and 1 May 1918, seven meticulously detailed articles appeared condemning such activity. Notwithstanding Spain's continual denial, the reports initially emphasised the existence of relations between Germany and Raisuli. 82 A few days later, alleged German proposals to Raisuli were exposed. They highlighted Germany's ambition of claiming sovereignty over Spanish Morocco following a tribal revolution, and their promise to provide unlimited authority over the Northern provinces to Raisuli. It was also suggested that these plans would follow their imminent offensive in France. 83 The campaign culminated with two articles published on 31 April and 1 May. The articles purported the existence of a German controlled region running continuously from the straits of Gibraltar through to the Algerian frontier and down into the French Protectorate. German sabotage was allegedly coordinated at Melilla, Tetouan, and Larache in the Spanish zone. At Tetouan, Bohn the acting German consul, Glasser, and Schumacher, supposedly employed numerous agents and passed instructions to Raisuli. Melilla supposedly served a similar purpose for Abdel Malek. Reischlag, Coppel and Tausent were supposedly employed to 
forward arms, munitions, and money to assist Malek's cause. ${ }^{84}$ The remaining circumstantial evidence suggests that these articles were at least partially informed by Room 40's intelligence. Young's contention that Room 40 was able to defeat several German intrigues in the region intimates that they at least administered some form of response, and in his semi-autobiographical history of NID during the WWI, Hall commended the significance of the press to intelligence work. Though there is no mention of Moroccan intrigues, he gave particular reference to Lord Northcliffe's publications, The Times and The Daily Mail, as the source of several successful outcomes. 85 His propensity for independently disclosing intelligence to the press was also characteristic of his tenure as Director of Naval Intelligence. Although it was undoubtedly a forgery, Hall is often considered responsible for leaking the infamous Zinoviev Letter to the Daily Mail in 1924, given that it was 'entirely consistent with his earlier career' 86

According to Foreign Office sources in Morocco, Walter Harris, The Times correspondent in Tangier allegedly responsible for the articles, received a report disclosing German proposals to Raisuli, but neither the British nor the French authorities received any confirmation that such a report ever existed. 87 Nor were they ostensibly aware of the specific details of German plots in the region. 88 Harris' character as a keen adventurer and staunchly patriotic expat, however, made him an ideal candidate for surreptitiously disclosing intelligence. ${ }^{89}$ As well as working as a semi-official British propagandist, in an autobiographical note of his wartime career, Harris actually professed to have worked for the 'Admiralty's Intelligence Department' between October 1917 and April 1918.90 
Although this collaboration was supposedly a one sided affair in which Harris passed NID detailed reports on the Moroccan situation, correspondence with his editors suggests that it was more reciprocal than Harris cared to admit. Although he had authored a number of unpublished articles in 1917 on Abdul Malek and Raisuli, that briefly mentioned the 'anti-ally activities' of Germany, he never explicitly or directly referred to any intrigues beyond mere propaganda. 91 Nor are his telegrams to the editorial staff particularly revealing in regard to German espionage. 92 Thus, his detailed analyses of German covert operations did not appear until a later date, which not only coincided with his purported cooperation with NID, but also, the arrival of Commander Cozens-Hardy of the Naval Intelligence Department in late 1917. Not only does this meeting directly connect him to NID, Harris insisted that his editors refrain from publishing his earlier articles until they had also consulted Cozens-Hardy.93 The Admiralty allegedly also requested that their publication be postponed.94 The Times received Harris' detailed revelations of German intrigues, therefore, at the exact point at which he was supposedly touring Morocco accompanied by CozensHardy. 95

Shortly before the beginning of the press campaign, the Foreign Office were considering an official protest regarding Spain's continual failure to inhibit German interference, but Hall insisted they refrain from doing so. 96 Given that the King had recently demonstrated a preference for dispensing with a Prime Minister rather than severing relations with Berlin after a U-boat attack on a Spanish vessel, any official complaint would have been equally disregarded.97 Hall's reluctance for Foreign Office intervention likewise suggests that he was cognisant of an alternative solution, and the timing of his interjection suggests that it was most likely the press campaign featured in The Times. The total 
exclusion of El Hiba throughout the press campaign is also surprising had it been a purely journalistic endeavour, given that he had previously constituted the greatest threat to Morocco. 98 But by 1918, Room 40 had demonstrated that support for Hiba had been significantly constrained, and German support for Malek and Raisuli had become far more pressing. Consequently, Hall's primary concern was to provoke opposition to Germany's clandestine activities in Spain, and there was little incentive to disclose the awareness of German involvement with El Hiba.

Although confirming whether The Times categorically revealed Room 40's intelligence is incredibly difficult, there is a compelling case suggesting that Harris provided the platform for NID to influence Spanish policies in Morocco, whilst simultaneously maintaining the anonymity of Room 40 . While there is some evidence that suggests other sources of information were more pertinent, it is often vague, contradictory, or hyperbolic. Mason, for instance, publically accredited himself with preventing German money getting into the hands of Moroccan rebels, but the 'exact means [he] employed can no longer be discovered'. 99 The surviving reports he provided the Foreign Office equally fail to substantiate his efficacy, given that they omit any detailed revelations of German machinations and were instead focused on the competency of French colonial management and infrastructure. 100 In any case, Mason had completed his work in Morocco by 1916 and became primarily concerned with secret service work in Spain, which would have made any personal intervention somewhat problematic. 101

The Consular Service provided the most notable source of human intelligence in Morocco, but although the Vice-Consuls at Larache and Tangier claimed to be intercepting communication between German agents and tribesmen, it is 
doubtful that this was particularly effective. 102 As first secretary at Tangier, Jack Garnett monitored German activities and produced 'evidence' of night signalling to submarines off the Moroccan coast, but this information merely inferred German involvement with Moroccan insurgents based on local hearsay. 103 Writing to Cozens-Hardy in late 1917, Garnett expressed his desire to 'get the Germans cleared bag and baggage out of the Spanish zone', but that his efforts were frustrated owing to the difficulty of obtaining evidence of Germany's transgressions. ${ }^{104}$ Garnett himself described the British consular service in Morocco as 'so small as to cause what I could only call

[a] waste of men, time, and money', and with no Vice-Consul at Melilla, they remained uninformed of specific intrigues involving Raisuli, which were to feature heavily in the press campaign. 105 Hall even personally intervened to prohibit the establishment of a Vice-Consul at Melilla, again implying that he was diligently monitoring the situation in Morocco.106 The majority of reports produced by consular agents, therefore, merely depicted presumed German interactions with local tribesmen. 107 Although Garnett had successfully infiltrated Germany's postal system in Morocco, which betrayed propaganda efforts in the region, it provided little insight into their clandestine operations. 108 Rather than the instigator of any press releases, Garnett actually attempted to suppress Harris' earlier reporting owing to discussions supposedly underway in Paris and London. 109

The subsequent correspondence between Berlin and Madrid implied that the press campaign had deeply unsettled the German representatives in Madrid. German mitigations eagerly denied the accusations and insisted that Britain was merely attempting to generate hostility between Spain and Germany on account of recent setbacks in France. ${ }^{110}$ The démenti proved temporarily successful. ${ }^{111}$ 
Following the publication of 'A German Zone in Morocco', the most substantial criticism of Germany's efforts in the region, the Madrid embassy expected a far more unsympathetic response. 112 Kalle was afraid that the intelligence bureau at Melilla would shortly be closed and there were further fears that the Ambassador, the secretary, and both attachés would be expelled. 113 In reply to complaints made by the German embassy, however, the Spanish authorities repeatedly stated that they paid no attention to the reports whatsoever, and only took action against the conspirators following intense pressure from the Entente. But in June, Spain eventually ousted four German agitators who had been supporting the Malek operation. 114

The weight of the press campaign was such that the Sultan bestowed an order of merit upon Walter Harris for exposing German support for Moroccan insurgents. 115 During the opening months of 1918, Malek had reportedly received substantial quantities of ammunition and financial support from Melilla, which the British believed to be financing a considerable militia and increasing activities against the French. ${ }^{116}$ Following the political difficulties with Spain and the dismissal of German agents from Melilla, German support for Malek declined. In late June 1918, Kalle informed Berlin that it was no longer possible to offer Malek financial assistance, nor was it feasible to send arms and munitions. ${ }^{117}$ The General Staff in Berlin concurred.118 Following Germany's inability to provide assistance, French operations against Malek proved immediately effective. According to Foreign Office sources, two engagements in July resulted in the death of four Germans and 300 tribesmen with only five French fatalities and sixteen wounded.119 The resulting impact on German support for Raisuli was less significant. Agents supporting Raisuli from Larache had already been expelled in February, before the publications in The Times came to light. 120 
Moreover, the British calculated that his prolonged inactivity had left him increasingly unpopular among the tribes and he began losing support and influence.121 Although Germany's financial support to Raisuli persisted, he continued to oscillate between Germany and Spain in order to maintain support from both and enhance his own personal agenda.

Whilst this episode reveals a greater use of signals intelligence, the strategic significance outweighed the operational effectiveness. Hall's use of the press in 1918 proved an effective technique to limit German covert activities in Morocco while simultaneously concealing the secrets of Room 40. Despite the influence of the press campaign and the eventual decline of German assistance, NID's operational success remained modest. Besides the minor setback achieved in 1917, the impact of signals intelligence only materialised around June 1918, but Room 40 first discovered German intrigues with Malek and Raisuli in June of 1916. Although this abeyance was generated by insurmountable political difficulties, there was nevertheless a two-year period where Germany was able to assist both rebels almost entirely unimpeded. 122 Thus, aside from the limited strategic gains in 1918, this belated response inevitably led to considerable operational difficulties for the colonial authorities and hardly amounts to another sensational success befitting the traditional Room 40 narrative.

\section{The impact of signals intelligence}

In 1919, Louis Barthou, a former French Prime Minister, claimed that, of the three allied powers maintaining possessions in North Africa, France suffered the least political dissidence and were even able to expand their authority in Morocco. 123 The British Secretary of State for Foreign Affairs, George Curzon, however, held a rather different view. As Minister for Foreign affairs from 1917, it was in Barthou's interest to suggest that his tenure fashioned a period of peaceful 
colonial relations. Curzon contended that there were several extremely critical moments in Morocco during the war and only through tireless military activity was their position upheld. 124

Despite Barthou's contention, peace was an illusion even after the Armistice. Raisuli finally launched an open rebellion against the Spanish in 1919 and although French forces repeatedly pushed Malek back, he was reportedly able to reappear fully supplied and capable of renewing the offensive. 125 The severity was amplified in the Spanish zone as years of inactivity against German intrigues had led to excessive amounts of arms remaining within easy reach of insurgents. Raisuli's forces were thus allegedly able to conduct daily skirmishes against the Spanish along with larger, more deadly engagements. 126

By July 1921, Spain's military power in Morocco had all but collapsed. Following considerable defeats and widespread desertion among their Moroccan soldiers, the eastern occupied regions revolted and Spain's defensive positions were either overwhelmed or abandoned. The Eastern Command lost 8668 men, including its commanding officer, 117 guns, and all the land gains made since 1909.127 What began as a Spanish-Berber war over control of the Rif highlands eventually became a predominantly French-Berber conflict. Marshall Philippe Pétain described it as a war fought against 'the most powerful and best armed enemy we have ever encountered in colonial operations'. By 1926, over 2000 soldiers had been killed and over 8000 wounded, far exceeding any other colonial counterinsurgency during the 1920s. Having already spent close to one billion francs, Pétain recognised that victory would only be assured following a colossal expenditure of both blood and money. 128 
Although these developments materialised after German influence in the region had largely dissipated, the precarious situation in Morocco was captured in an intelligence report produced in October 1918. Despite the scarcity of evidence regarding Thoroton's work, a solitary report in the Foreign Office archives illustrates the gravity of the situation in Morocco and highlights the number of multifarious threats emerging in the French Protectorate. To maintain order in the Rif highlands, 80 per cent of Lyautey's mobile forces were concentrated in the north-eastern regions, leaving only 2000 soldiers to defend Marrakesh against the incursions of El-Hiba, whilst simultaneously required to repel Abdul Malek's operations $100 \mathrm{~km}$ away. French forces were being stretched to the limit and Thoroton considered their authority to be hanging by a thread, 'and that thread was wearing thin'. The Spanish, he argued, were utterly impotent, confined to their fortified towns and unable to defend their isolated posts. He alleged that their position had become so untenable by 1918 that a Pan-Islamic rising able to spread throughout North Africa would almost certainly follow any further military defeat suffered by the colonial powers. ${ }^{129}$ Fortunately for the European authorities, victory in France less than two months later alleviated the situation and helped prevent such catastrophic circumstances from arising. In spite of Room 40's detailed awareness of German operations, the situation in Morocco was only improved with the influx of French troops following the Armistice. By their own admission, therefore, NID had demonstrated little impact against German operations in the region. As the war progressed, Moroccan dissidents secured growing success and power, and the authority of the French was increasingly destabilised despite Room 40's awareness of German operational support. Despite the cumulative strength of Moroccan insurgents, their ultimate failure to achieve independence most likely resulted from the problems inherent within Moroccan nationalism, rather than the deployment of British signals intelligence. Since Morocco contained a multitude of ethnicities both racially 
and linguistically separated, the distinctions between Berber and Arab and town and tribal discouraged the formation of a national identity. The ability of any insurgent to unite the country against European domination, therefore, was an exceedingly problematical undertaking. 130

\section{Conclusion}

This paper has argued that secrecy remained paramount up to 1917. Although Room 40 had acquired an intimate awareness of German plans for Hafid, Hall chose not to share that information beyond the Admiralty. As a consequence, neither Hall nor diplomatic cryptanalysis could have any operational impact. Given that this was a relatively novel source of intelligence that also went beyond their traditional naval remit, the insistence to maintain secrecy was undeniably prudent, but it nonetheless constrained its influence. Although by the end of 1916 the importance of intelligence dissemination had been cautiously recognised, even between Allied partners, the operational potential of cryptanalysis had not yet been fully realised. But by 1918, as the response to Abdul Malek and Raisuli suggests, the confidence and ability to independently deploy intelligence had emerged. By analysing a series of consecutive responses, therefore, it becomes clear that the impact of signals intelligence reflected the wider development of British cryptanalysis. Just as the formation of code breaking organisations in 1914 represented the logical culmination of an emerging trend, Room 40's operational impact was equally reliant on evolutionary rather than revolutionary advances. 131

Although Young professed that Room 40's intelligence made it possible to defeat German intrigues in Morocco, the surviving evidence intimates that despite the advances made in intelligence deployment, the significance of signals intelligence in this instance was inconsequential. Although it caused some minor strategic 
setbacks to German designs, the absence of any substantial operational impediment resulting from Room 40's intelligence allowed German backed insurgents to continue their campaigns against the French and have an enduring impact upon their colonial ambitions. The landing of the submarine resupplying Hiba and the delayed response to both Malek's and Raisuli's insurgencies, for instance, both led to immediate difficulties for the French, and to a lesser extent the Spanish, that were to continue beyond the Armistice in 1918.

Exposing Germany's Moroccan intrigues also further reiterates the scale of the intelligence war between 1914 and 1918. Since it was conducted over multiple continents and involved an unprecedented number of belligerents, influencing politics and diplomacy on such a vast scale was too ambitious for any individual. 132 But the implied difficulties in intelligence collaboration with the French in 1916 and the nature of Hall's response to Raisuli and Malek in 1918, both demonstrate a penchant for independently controlling intelligence. A committee examining the work of NID during the war found that Hall had too often personally intervened in diplomatic affairs using Room 40's interceptions; intelligence that they deemed should have been passed immediately to the Foreign Office. $133 \mathrm{Had}$ he been more forthcoming in his willingness to distribute intelligence, and the relevant British and French authorities made fully aware of Germany's clandestine activities, managing a coordinated response could have generated a far more effective policy in preventing German support from materialising in the region. 


\section{Notes}

1. The National Archives (TNA) ADM 223/773, Memo on "Political" Branch of Room 40 by George Young, 3, 4.

2 TNA ADM 1/23899, Lecture by Sir James Ewing on the work of Room 40 in the WWI (1927), 16; Beesly, Room 40; Andrew, Secret Service, 139-94; and Kahn, The Code-Breakers, 266-97.

3. The exception to this is Hoy, 40 O.B., discussed below.

4. James, The Eyes of the Navy, 34.

5. Gannon, Inside Room, 40, 180, 181.

6. Wyllie and McKinley, Code Breakers, 132-9. A similar account can be found in Stafford, The Silent Game, 74-7.

7. West, "Fiction, Faction and Intelligence"; Scott and Jackson, "The Study of Intelligence," 145; and Scott, "Secret Intelligence," 326.

8. Memo on "Political" Branch of Room 40 by George Young, 4.

9. For an overview of the traditional historical narrative see Christenson, "Review of Inside Room 40," 282-8.

10. Freeman, "MI1(b)," 223, 217; Boghardt, The Zimmermann Telegram, 180, 90, 242, 80-90; Larsen, "Mediation Mission," 697-701. Jason Hines has already demonstrated the limitations of Room 40's naval signals in an operational context: "Sins of Omission," 1117-54.

11. O'Halpin, "British Intelligence in Ireland," 57-60; Ferris, "Whitehall's Black Chamber," 55, 56; Ferris, Selected Essays, 99-102; and Larsen, "Mediation Mission," 701.

12 Fisher, "An Eagle Whose Wings Are Not Always Easy to Clip," 156.

13. Burke, "Pan Islam and Moroccan

Resistance," 106. 14. Ibid., 107.

15. Alexander, Europe's Uncertain Path, 290, 291.

16. "Lyautey's Triumph," The Times, December 29, 1915, p.6.

17. TNA HW 7/29, Berlin-Madrid No.724, October 23, 1915; For German covert operations and Zimmermann's involvement see Boghardt, Zimmermann Telegram, 29.

18. TNA HW 7/28, Madrid-Berlin No.305, November 30, 1917; and Fisher, "Keeping 'the Old Flag Flying'," 730-3.

19. Dean, "France and Morocco During the Great War," 734-9.

20. Pennell, Morocco Since 1830, 181.

21. Burke, "Moroccan Resistance," 444-7.

22. Ibid., 444; Alvarez, "World War I: Unarmed Neutrality"; and Ponce, "Spanish Neutrality," 57-60.

23. TNA WO 106/6191, Organisation of Intelligence in Spain since August 1914, April 4, 1917; Vickers, Finding Thoroton, 82. 
24. Howe, Lyautey of Morocco, 325; and TNA FO 372/691 No.89229, “Moorish Decoration for Major C.J. Thoroton," July 5, 1915.

25. TNA ADM 137/2206: Mediterranean War Records Vol. 42, Reports of proceedings, Gibraltar, August 1917-November 1918; and Stafford, The Silent Game, 73-7.

26. "Sultan Muley Abdel Hafid," The Times, April 24, 1925, p.11; Harris, Morocco that Was, 116-8; and Berenson, Heroes of Empire, 257.

27. Bidwell, Morocco under Colonial Rule, 64, 65; and Burke, "Moroccan Resistance," 114.

28. Bidwell, Morocco under Colonial Rule, 65.

29. TNA ADM 223/654 and ADM 223/655, NID Message Logs.

30. TNA FO 371/2050 No.78891, “Ex-Sultan's Movements," December 4, 1914.

31. TNA FO 371/2414 No.109152, "Ex-Sultan Moulay Hafid," August 9, 1915; and TNA FO 566/1164, “Country: Morocco Series: War," August 6, 1915.

32. Hat codes, which contained the most sensitive information, were broken during the course of 1916. Memo on "Political" Branch of Room 40 by George Young, 3, 4.

33. FO 371/2414 No.172278, "Mulai Hafid: His Distress at Alleged Suspicions of British Government, "November 16, 1915.

34. TNA HW 7/31, Berlin-Madrid No.114, March 5, 1916.

35. TNA FO 371/2712 No.79831, "Ex-Sultan of Morocco," April 28, 1916.

36. FO 371/2712 No.92988, "Activities of Muley Hafid," May 16, 1916.

37. HW 7/31, Berlin-Madrid No.509, June 15, 1916.

38. HW 7/31, Madrid-Berlin No.343, June 7, 1916; and TNA ADM 223/646, NID Message Logs No.323, September 9, 1916.

39. HW 7/29, Berlin-Madrid No.724, October 27, 1915.

40. Whereas French intelligence had already set a precedent for coordinating collaborative responses, see TNA 369/741 No. 83988, "Pan-Islamic Agent, Bebdton," December 18, 1914.

41. HW 7/29, Berlin-Madrid No.547, June 30, 1916. 
42. James, Eyes of the Navy, 90.

43. Larsen, "Mediation Mission," 695-701.

44. HW 7/29, Madrid-Berlin No.1926, December 14, 1915.

45. HW 7/29, Madrid-Berlin No.188, August 1, 1916 and Madrid-Berlin No.217, August 14, 1916.

46. See note 44 above.

47. HW 7/29, Berlin-Madrid No.779, August 22, 1916.

48. HW 7/29, Berlin-Madrid No.725, October 27, 1915.

49. HW 7/29, Berlin-Madrid No.827, December 17, 1915.

50. HW 7/29, Berlin-Madrid No.547, June 30, 1916.

51. HW 7/29, Berlin-Madrid No.779, August 22, 1916; HW 7/29, Madrid-Berlin No.246, August 24, 1916; ADM 223/646, NID Message Logs No.889, September 20, 1916, No.915 25 September 1916.

52. HW 7/29, Berlin-Madrid No.826, September 4, 1916.

53. HW 7/29, Madrid-Berlin No.343, October 7, 1916; and TNA ADM 223/647, NID Message Logs No.370, October 6, 1916.

54. ADM 223/647, NID Message Logs No.1046, October 27, 1916.

55. TNA ADM 223/649, NID Message Logs No.1284, December 15, 1916 and No.512, January 6, 1917.

56. HW 7/29, A handwritten note on the report from Captain Kelly, the naval attaché in Paris, to the Admiralty, November 25, 1916.

57. HW 7/29, Madrid-Berlin No.261, January 30, 1917; TNA ADM 223/651, NID Message Logs, No.106, February 7, 1917; and HW 7/29, Madrid-Berlin No.328, February 6, 1917.

58. HW 7/29, Madrid-Berlin No.27, January 9, 1917 and Berlin-Madrid No.674, July 11, 1917; and ADM 223/651, NID Message Logs No.155, February 10, 1917.

59. Freeman, “MI1(b)," 214.

60. Churchill College Archive Centre (CCAC), British Naval Intelligence Papers, MLBE 5/1 The Papers of Commander Lloyd Hirst; James, Eyes of the Navy, 204; and Beesly, Room 40, 191-200.

61. Burke, "Moroccan Resistance," 446; and Bartels, Fighting the French, 105.

62. Woolman, Rebels in the Rif, 114.

63. Harris, Morocco that Was, 179, 180.

64. "Raisuli," The Times, December 27, 1906; and Pennell, Morocco Since 1830, 170-1.

65. Chandler, "Spain and Her Moroccan Protectorate," 309.

66. Cambridge University Library Manuscripts, Hardinge Papers, volume 25: Sir Arthur Hardinge to Charles Hardinge, September 19, 1916, f.199; TNA CAB 24/28/28, Weekly report on Spain XI, Intelligence Bureau, October 4, 1917; TNA FO 371/2970 No.166083, "Recent Fighting in French Zone," August 24, 1917; and Ponce, "Spanish Neutrality," 55-7. 
67. FO 371/2970 No.176118, "Spanish Zone in Morocco," September 10, 1917; and TNA CAB 24/17/11, Weekly report on Spain III, Intelligence Bureau, June 20, 1917.

68. Hertog and Kruizinga, "Introduction," 8.

69. Bennett, The Zinoviev Letter, 45, 46; and Pincher, "Reflections," 149-55.

70. TNA HW 7/30, Berlin-Madrid No.551, July 1, 1916.

71. TNA ADM 223/652, NID Message Logs No.180, March 4, 1917; and HW 7/30, Madrid-Berlin No.601, August 18, 1917.

72. HW 7/30, Madrid-Berlin No.601, August 18, 1917.

73. TNA FO 371/2969 No.21873, "Raisuli and Spanish Authorities," January 27, 1917 and No.116086, "Raisuli: Proposal of Spanish Government to Appoint him Grand Vizier," June 11, 1917.

74. HW 7/30, Madrid-Berlin No.623, September 8, 1917.

75. HW 7/30, Madrid-Berlin No.4522, December 6, 1917.

76. CACC, The Papers of Admiral Sir Reginald Plunkett-Ernle-Erle-Drax, DRAX 5/3 World War I Intelligence Reports, 'Admiralty Intelligence Reports on the International Situation and General Intelligence' No.221.

77. HW 7/30, Madrid-Berlin No.200, March 10, 1917, Madrid-Berlin No.258, March 29, 1917.

78. HW 7/28, Madrid-Berlin No.231, March 20, 1917; and HW 7/30, BerlinMadrid No.358, April 1, 1917.

79. ADM 223/652, NID Message Logs No.358, March 31, 1917; and HW 7/30, Berlin-Madrid No.397, April 10, 1917. 80. Hoy, 40 O.B., 179, 180.

81. "The French Zone," The Times, December 27, 1915; "French Anxiety," The Times, December 28, 1915; and "Lyautey's Triumph," The Times, December 29, 1915.

82 "Raisuli and the Germans," The Times, April 4, 1918; and "Raisuli's Son a German Protégé," The Times, April 5, 1918.

83. "German Proposals to Raisuli," The Times, April 8, 1918.

84. "A German Zone in Morocco I," The Times, April 31, 1918; and "A German Zone in Morocco II," The Times, May 1, 1918.

85. CCAC, The Papers of Admiral Sir William Reginald Hall, HALL 3/4, "chapter 6, 'A little 'information' for the enemy."

86. Chester et al., The Zinoviev Letter, 95-8; Andrew, Secret Service, 437; Bennett, The Zinoviev Letter, 45, 46; Andrew, Defence of the Realm, 150; and Boghardt, Zimmermann Telegram, 238.

87. TNA FO 371/3252 No.86403, "Tribal Unrest and Enemy Agents," May 15, 1918.

88. TNA FO 371/3251 No.61256, "Enemy Activities at Larache," April 6, 1918. British diplomats in Tangier repeatedly lambasted the futility and boredom of their Moroccan postings: Fisher, "The Strange Life of W.J. Garnett," 208. 
89. Lancashire Record Office, Jack Garnett Papers, DDQ/44/1, Hardinge to Garnett, June 3, 1909; Fisher, "Keeping 'the Old Flag flying'," 719-46.

90. Times Newspapers Ltd Archive (TNL), Walter Harris Papers, WBH/2, Unsigned note, January 29, 1919; Hardinge Papers, volume 34: Sir Arthur Hardinge to Charles Hardinge, October 16, 1917, f.364; Fisher, "An Eagle Whose Wings are not Always Easy to Clip," 156-9.

91. TNL, Geoffrey Dawson Papers, TT/ED/GGD/1, Harris to Dawson, September 18, 1916 and December 31, 1917; TNL, Henry William Stead Papers, TT/ED/HWS/1, "Raisuli and Tangier," July 12, 1917; and Harris, France, Spain and the Rif, 58.

92 Harris Papers, WBH/2, Telegrams and Messages from Harris.

93. Stead Papers, Undated telegram Harris to Stead.

94. Stead Papers, Harris to Stead, October 14, 1917.

95. TNL, Basil Long Papers, TT/FE/BKL/1, Long to Harris, April 23, 1918; Dawson Papers, Harris to Dawson 22-28 April 1918. Cozens-Hardy and Harris' partnership continued until 1919 for the War Trade Intelligence Department: Fisher, "The British Community in Morocco," 738.

96. FO 371/3251 No.79446, "Surreptitious Activities of the Germans at Larache," May 4, 1918.

97. Ponce, "Spanish Neutrality," 62.

98. Harris also appeared to be unaware of intrigues with Muley Hafid, which further questions whether the reports were a product of an independent inquiry. Harris, Morocco that Was, 158.

99. His biographer relied upon his three fictional accounts of what transpired in Morocco: Green, Mason, 142-3.

100. TNA FO 371/2714 No.262856, "Mr A.E.W. Mason's Visit to General Lyautey," December 28, 1916.

101. Which was in any case concluded by the end of 1916: Green, Mason, 144-7. 102 TNA FO 369/941 No.148973, "Consular Staff Morocco," July 28, 1917; and No.190804, "Assistance for Vice-Consul Atkinson at Tetuan," October 4, 1917; and Garnett Papers, DDQ 9/47/125, Garnett to Cozens-Hardy, January 18, 1918.

103. This was based on sketchy evidence provided by casual informants and collected by Lewis Forde. Forde offered very little in terms of definitive proof of covert activities or that the Germans were connected to the activities being monitored. Garnett Papers, DDQ 9/45/46-7, Macleod to Garnett, April 24-26, 1917; and DDQ 9/45/51, Macleod to Garnett, April 30, 1917. In reply to this evidence, Sir Arthur Hardinge stated that unless Garnett was 'able to [provide] very positive evidence indeed to work upon', the matter would not be taken up with the Spanish: Garnett Papers, DDQ 9/45/90, Lorain to Garnett, July 4, 1917. See also Fisher, British 
Diplomacy, 150, 151.

104. Garnett Papers, DDQ 9/47/75, Garnett to Cozens-Hardy, November 17, 1917; and DDQ 9/47/107, Garnett to Cozens-Hardy, December 18, 1917.

105. FO 369/941 No.171401, "Future Consular Arrangements and Commercial Prospects in Morocco," September 1, 1917; and FO 369/941 No.227458, "Creation of a Consular Post at Port of Melilla," November 29, 1917.

106. TNA FO 369/1006 No. 9432, "Appointment of a British Vice Consul at Melilla," January 16, 1918.

107. FO 371/3251 No.61256, "Enemy Activities at Larache," April 6, 1918.

108. Garnett Papers, DDQ 9/45/108, Selous to Garnett, July 25, 1917.

109. Garnett Papers, DDQ 9/47/16, Garnett to Cozens-Hardy, October 7, 1917.

110. HW 7/30, Madrid-Berlin No.460, April 13, 1918.

111. HW 7/30, Madrid-Berlin No.212, April 18, 1918.

112 HW 7/30, Madrid-Berlin No.1719, May 5, 1918.

113. HW 7/30, Madrid-Berlin No.1868, May 20, 1918.

114. FO 371/3251 No.106441, “Application from Spanish Government for Safe Conduct for Four Germans," June 14, 1918.

115. TNA FO 372/1144 No.141706, "Moorish Decoration for Mr Harris," August $16,1918$.

116. FO 371/3252 No.48938, "Tribal situation in Spanish Zone," March 16, 1918, No.113748, "Tribal Unrest (French Zone)," June 27, 1918.

117. HW 7/30, Madrid-Berlin No.2431, June 29, 1918.

118. HW 7/30, Berlin-Madrid No.30676, August 31, 1918.

119. FO 371/3252 No.123876, "Abdul Malek, Reports Defeat of Two Forces by French," July 15, 1918.

120. FO 371/3251 No.23978, "Germans at Larache," February 7, 1918.

121. FO 371/3252 No.48938, "Tribal Situation in Spanish Zone," March 16, 1918.

122. Garnett Papers, DDQ 9/49/65 Cozens-Hardy to Garnett, November 10, 1917.

123. TNA FO 371/3839 No.149556, "Du Bataille du Maroc," November 7, 1919.

124. FO 371/3839 No.167775, "French Protectorate during the War," December 5, 1919. Walter Harris similarly contended that General Lyautey's industrious and persistent military endeavour held Morocco together: France, Spain and the Rif, 193.

125. "Germany's Moroccan War," The Times, October 22, 1918; TNA FO 371/3840 No.21132, "Raisuli," February 7, 1919, and No.36100, "Military Situation: French Zone," March 6, 1919; and Bartels, Fighting the French, 113-94.

126. TNA FO 371/3841 No.134007, "Fighting in Spanish Zone," September 26, 1919; and FO 371/3840 No.105733, "Military Operations: Spanish Zone," July 22, 1919.

127. Chandler, "Spain and Her Moroccan Protectorate," 311-2.

128. Terhorst, The Riff Kabyles, 9-22; and Thomas, "Crisis Management in Colonial States," 703, 704. 
129. TNA FO 371/3253 No.120729,"Situation in Morocco, Report by Col.

Thoroton on Gravity of Situation, and Possible Measures for Its Amelioration," July 10, 1918.

130. Cline, "Nationalism in Morocco," 18.

131. Ferris, "Before 'Room 40'," 431; and Ferris, "The Road to Bletchley Park," 53.

132. SIGINT's considerable impact on the Second World War was largely thanks to Churchill's appreciation of it's role in international relations and of the need to coordinate the intelligence process: Andrew, "Churchill and Intelligence," 187.

133. Wells, "Studies in British Naval Intelligence," 99.

\section{Acknowledgements}

I should first like to thank the original markers of the MA thesis that this article was based on, William Philpott and Richard Ned Lebow. Thanks must also go to Anthony Kauders, Siobhan Talbott and Matthew Seligmann for their helpful comments on earlier drafts of this research. Special thanks to Jim Beach for feedback and guidance throughout the various stages of this project, and Philip Morgan for showing a tremendous patience and willingness to read and comment on several forms of this article.

\section{Disclosure statement}

No potential conflict of interest was reported by the author.

\section{Notes on contributor}

Harry Richards is a PhD researcher in the Department of History at Keele University. His research evaluates the cultural impact of spy fever in Britain during the WWI. 


\section{Bibliography}

Alexander, Rob. Europe's Uncertain Path, 1814-1914: State Formation and Civil Society. Oxford: Wiley-Blackwell, 2012. Alvarez, Josâe E. "World War I: Unarmed Neutrality." In A Military History of Modern Spain: From the Napoleonic Era to the International War on Terror, edited by Wayne H. Bowen and Josâe E. Alvarez, 5367. London: Praeger Security International, 2007.

Andrew, Christopher. "Churchill and Intelligence." Intelligence and National Security 3, no. 3 (1988): 181-193. Andrew, Christopher. Defence of the Realm: The Authorised History of MI5. London: Penguin, 2010. Andrew, Christopher. Secret Service: The Making of the British Intelligence Community. London: Sceptre, 1986. Bartels, Albert. Fighting the French in Morocco. Translated by H. J. Stenning. London: A. Rivers, 1932.

Beesly, Patrick. Room 40 British Naval Intelligence 1914-18. London: Hamilton, 1982.

Bennett, Gill. 'A Most Extraordinary and Mysterious Business': The Zinoviev Letter of 1924. London: Foreign and Commonwealth Office, 1999.

Berenson, Edward. Heroes of Empire: Five Charismatic Men and the Conquest of Africa. London: University of California Press, 2011.

Bidwell, Robin. Morocco under Colonial Rule: French Administration of Tribal Areas 1912-1956. London: Cass, 1973. Boghardt, Thomas. The Zimmermann Telegram Intelligence, Diplomacy, and America's Entry into World War I. Annapolis, MD:

Naval Institute Press, 2012.

Burke, Edmund. "Moroccan Resistance, Pan-Islam and German War Strategy, 1914-1918." Francia 3 (1975): 434-464. Burke, Edmund. "Pan Islam and Moroccan Resistance to French Colonial Penetration 1900-1912." The Journal of African

History 13, no. 1 (1972): 97-118.

Chandler, James A. "Spain and Her Moroccan Protectorate 1898-1927." Journal of Contemporary History 10, no. 2 (1975): 301-322.

Chester, Lewis, Stephen Fay, and Hugo Young. The Zinoviev Letter: A Political Intrigue. London: Heinemann, 1967. Christenson, Chris. "Review of Inside Room 40: Codebreakers of World War I." Cryptologia 35, no. 3 (2011): 282288. Cline, Walter B. "Nationalism in Morocco." Middle East Journal 1, no. 1 (1947): 18-28.

Dean, William T. "Strategic Dilemmas of Colonization: France and Morocco

During the Great War." The Historian 73, no. 4 (2011): 730-746.

Ferris, John. "Before 'Room 40': The British Empire and Signals Intelligence, 18981914.' Journal of Strategic Studies 12, no.

4 (1989): 431-457. 
Ferris, John. Intelligence and Strategy: Selected Essays. Abingdon: Routledge, 2005.

Ferris, John. "The Road to Bletchley Park: The British Experience with Signals Intelligence, 1892-1945." Intelligence and National Security 17, no. 1 (2002): 53-84.

Ferris, John. "Whitehall's Black Chamber: British Cryptology and the Government Code and Cypher School, 1919-29." Intelligence and National Security 2, no. 1 (1987): 54-91.

Fisher, John. British Diplomacy and the Descent into Chaos: The Career of Jack Garnett, 1902-19. Basingstoke: Palgrave-Macmillan, 2012.

Fisher, John. 'An Eagle Whose Wings Are Not Always Easy to Clip': Walter Burton Harris' in On the Fringes of Diplomacy: Influences on British Foreign Policy, 1800-1945, edited by John Fisher and Antony Best. Abingdon: Routledge, 2011.

Fisher, John. "Keeping 'the Old Flag Flying: The British Community in Morocco and the British Morocco Merchants Association, 1914-24." Historical Research 83, no. 222 (2010): 719-746.

Fisher, John. "The Quest': The Strange Life of W.J. Garnett." Diplomacy and Statecraft 15, no. 2 (2004): 197-219.

Freeman, Peter. "MI1(b) and the Origins of British Diplomatic Cryptanalysis." Intelligence and National Security 22, no. 2 (2007): 206-228.

Gannon, Paul. Inside Room 40: The Codebreakers of World War One. Hersham: Ian Allan, 2010. Green, Roger Lancelyn. A.E.W.

Mason. London: M. Parrish, 1952.

Harris, Walter B. France, Spain and the Rif. London: 1927.

Harris, Walter B. Morocco that Was. London: Blackwood and Sons, 1921. Hertog, Johan Den, and Samuël Kruizinga. "Introduction." In Caught in the Middle: Neutrals, Neutrality and the First World War, edited by Johan Den Hertog and Samuël Kruizinga, 1-14. Amsterdam: Aksant, 2011.

Hines, Jason. "Sins of Omission and Commission: A Reassessment of the Role of Intelligence in the Battle of Jutland." The Journal of Military History 72, no. 4 (2008): 1117-1154.

Howe, Sonia E. Lyautey of Morocco: An Authorised Life. London: Hodder and Stroughton, 1931. Hoy, Hugh Cleland. 40 O.B. Or How The War Was Won. London: Hutchinson, 1932.

James, W. M. The Eyes of the Navy: A Biographical Study of Admiral Sir Reginald Hall. London: Methuen, 1955.

Kahn, David. The Code-breakers: The Comprehensive History of Secret Communication from Ancient Times to the Internet. New York: Scribner, 1996. Larsen, Daniel. "British Intelligence and the 1916 Mediation Mission of Colonel Edward M. House." Intelligence and National Security 25, no. 5 (2010): 682-704. O'Halpin, Eunan. "British Intelligence in Ireland, 1914-1921." In The Missing Dimension: Governments and Intelligence Communities in the Twentieth Century, 
edited by Christopher Andrew and David Dilks, 54-77. London: Macmillan, 1984. Pennell, C. R. Morocco Since 1830: A History. London: Hurst and Company, 2000. Pincher, Chapman. "Reflections on a Lifetime of Reporting on Intelligence Affairs." In Spinning Intelligence: Why Intelligence Needs the Media, Why the Media Needs Intelligence, edited by Robert Dover and Michael Goodman. London: Hurst, 2009: 149-164.

Ponce, Javier. "Spanish Neutrality during the First World War." In Caught in the Middle: Neutrals, Neutrality and the First World War, edited by Johan Den Hertog and Samuël Kruizinga, 53-66. Amsterdam: Aksant, 2011.

Scott, Len. "Secret Intelligence, Covert Action and Clandestine Diplomacy." Intelligence and National Security 19, no. 2 (2004): 322-341.

Scott, Len and Peter Jackson. "The Study of Intelligence in Theory and Practice." Intelligence and National Security 19, no.

2 (2004): 139-169.

Stafford, David. The Silent Game: The Real World of Imaginary

Spies. London: Thistle, 2013. Terhorst, Bernd. With the Riff Kabyles. London: Greenwood, 1926.

Thomas, Martin. "Crisis Management in Colonial States: Intelligence and Counterinsurgency in Morocco and Syria after the First World War." Intelligence and National Security 21, no. 5 (2006): 697-716.

Vickers, Phillip. Finding Thoroton: The Royal Marine who Ran British Naval Intelligence in the Western Mediterranean in World War One. Southsea: Royal Marines Historical Society, 2013.

Wells, Anthony Ronald. "Studies in British Naval Intelligence, 1880-1945." Unpublished PhD Thesis, King's College London, 1972.

West, Nigel. "Fiction, Faction and Intelligence." Intelligence and National Security 19, no. 2 (2004): 275-289. Woolman, David S. Rebels in the Rif: Abd El Krim and the Rif Rebellion. London: Oxford University Press, 1969.

Wyllie, James, and Michael McKinley. Code Breakers: The Secret Intelligence Unit that changed the course of the First World War. London: Ebury, 2015. 